\title{
THE INFLUENCE OF SUSTAINABLE SUPPLY CHAIN MANAGEMENT ON PERFORMANCE OF ORGANIC COFFEE IN PASURUAN REGENCY
}

\author{
Nikmah Husnaeni*, Dwi Retnoningsih \\ Department of Social Economics, Faculty of Agriculture, Brawijaya University \\ *corresponding author: nikmahhusnaeni@gmail.com
}

\begin{abstract}
Pasuruan Regency is the largest area of organic coffee in East Java, Indonesia that has a potential future competitive advantage, but organic coffee is currently still weak and has to compete with non-organic coffee and imported coffee. Increase competition and make a business become sustainable require the involvement of actors in the supply chain and sustainable principles. This study aims to analyze the influence of supply chain sustainable management on performance in organic coffee in Pasuruan Regency. This research conducted in Prigen and Tutor Districts, Pasuruan Regency, East Java, in March until April 2020. The data was gathered from 51 respondents who were determined using purposive sampling and the Rules of Thumb with SEM-PLS as the analysis technique. Based on SEM-PLS analysis, sustainable supply management practices have a sustainable positive effect on sustainable performance, except for sustainable supplier management on social performance and sustainable consumer management on environmental performance. This is due to the lack of involvement of all suppliers in the social activities of the community and consumers who are not oriented towards the environmental aspects of organic coffee.
\end{abstract}

Keywords: Sustainable Supply Chain Management, Performance, Sustainable Principles, Organic Coffee, Structural Equation Modelling

http://dx.doi.org/10.21776/ub.agrise.2021.021.1.2

Received 9 October 2020

Accepted 12 January 2021

Available online 31 January 2021

\section{INTRODUCTION}

The implementation of a sustainable supply chain has become a major issue to increase competitive advantage in the market and sustainable business. People realize that to improve competitive advantage, internal and external interactions are needed, such as actor in the supply chain (Haanaes, 2016). In addition, sustainable supply chain management needs to be adopted because a business must provide resilience from time to time in the market (Emamisaleh and Rahmani, 2017).

Implementation of sustainable supply chain needs to consider a system that supports three basic benchmarks of 3P, namely people, planet, and profit (Heizer and Render, 2015). The 3P concept represents a sustainable supply chain management that can optimize profits or benefits (economic aspects), people (social aspects), and environment (environmental aspect) (Bleomhoof, 2016). One of the commodities that need to have supply chain management with sustainable principles is coffee.

The prospect of coffee is high in Indonesia because it has an important role for the national economy and several regions produce coffee on a large scale, one of them is East Java (Directorate General of Plantation. , 2018). One area in East Java that has a contribution to coffee production in East Java is Pasuruan Regency. Pasuruan Regency is one of the biggest coffee producing regions in East Java. In 2015, coffee production in Pasuruan Regency reached 3,102 tons, and in the following years, it decreased to 2000. In 2017, coffee production in Pasuruan Regency reached 2,086 tons. Even though

CITATION: Husnaeni, N., Retnoningsih, R., (2021). The Influence of Sustainable Supply Chain Management on Performance of Organic Coffee in Pasuruan Regency, Agricultural Socio-Economics Journal, 21(1), 7-14 DOI: http://dx.doi.org/10.21776/ub.agrise.2021.021.1.2 
it has reduced, Pasuruan Regency is still one of the largest coffee producers in East Java apart from Malang, Probolinggo, Jember, Banyuwangi, and Lumajang Regencies (Directorate General of Plantation, 2018 and Agency Statistics Center, 2018).

Government of Pasuruan Regency is trying to improve the quality of their coffee products, one of which is by using an organic system. East Java BPS (2018) notes that East Java has twelve coffee regions that are certified organic and Pasuruan Regency, which has four of these areas. Organic coffee owned by Pasuruan Regency has future prospects and is sustainable, but for now, organic coffee still has to compete with non-organic coffee. Increasing competition and doing sustainable business on organic coffee involves several elements in the supply chain.

Sustainable supply chain management will impact performance. Sustainable performance, as reflection of activities carried out in the supply chain can be measured from the Triple Bottom Line Sustainability (TBL) which is social, environmental and economic performance and aims to help ensure a long-term supply of people, natural resources and profits (APICS, 2016).

There is not many research about the relationship of sustainable supply chain management with performance. Ahi and Searcy researched about the true definition of suspIn 2018, Lu, et al (2018) analyzed sustainable supply chain management from a social perspective. Then Narimissa, et al (2019) analyzed indicators in sustainable supply chain performance because they were aware of the importance of these indicators to assist companies in developing sustainable supply chains, which indicators are represented by the concept of a trilogy (Narimissa, et al., 2019). Based on some of these studies, this study will examine the practice of sustainable supply chain management in organic coffee commodities and their impact on sustainable performance in Pasuruan Regency.

\section{RESEARCH METHODS}

This research was conducted in Pasuruan Regency on March - April 2020. The determine respondents used purposive sampling and estimated by Rules of Thumbs for PLS-SEM. Hair, et al (2017) stated that the minimum sample must be more than equal to;
1. Ten times the largest number of formative indicators used in a single latent construct, or

2. Ten times, the largest number of structural paths directed at one latent construct.

Based on the Rules of Thumb, the minimum required respondents are 40 respondents from 10 times the numbers of formative indicators.

Partial Least Square Structure Equation Modeling (PLS-SEM) is used to analyze the causal relationship between many latent variables and can be used with a small number of samples (Astrachan, 2014 and Hair, et al., 2017). In this study, PLS-SEM technique is to analyze the influence of three exogenous variables (sustainable suppliers management, sustainable operations management, and sustainable consumer management) on three endegenous variables (environmental, social, and economic).

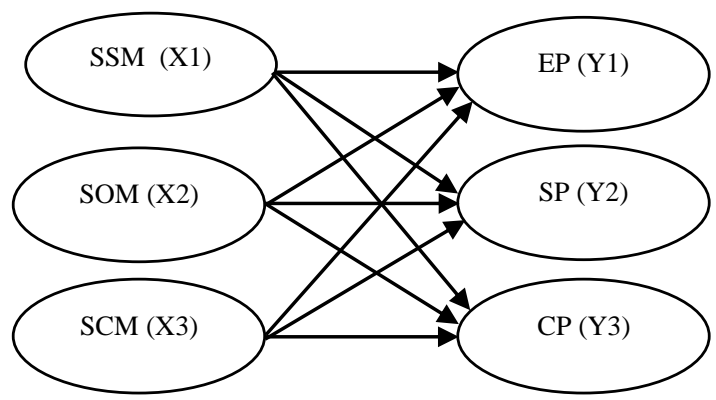

Figure 1. Research Model

The general equation in this research will be explained below.

$$
\begin{aligned}
& \mathrm{Y}_{\mathrm{i}}=\gamma_{1} \mathrm{X}_{1}+\gamma_{2} \mathrm{X}_{2}+\gamma_{3} \mathrm{X}_{3}+\zeta \\
& \mathrm{X}_{\mathrm{i} . \mathrm{i}}=\lambda_{\mathrm{i}} \mathrm{X}_{\mathrm{i}}+\ldots \lambda_{\mathrm{n}} \mathrm{X}_{\mathrm{n}}+\delta_{\mathrm{i}} \\
& \mathrm{Y}_{\mathrm{i}}=\lambda_{\mathrm{i}} \mathrm{Y}_{\mathrm{i} . \mathrm{i}}+\ldots .+\lambda_{\mathrm{n}} \mathrm{Y}_{\mathrm{n} . \mathrm{n}}+\varepsilon
\end{aligned}
$$

Equation (1) is an inner model that explain the relationship of dependent and independent variable relationships in $i=1,2, \ldots, n$. Equations (2) and (3) are the relationship between latent variable with the indicator, the measurement error vector of the independent variable, and the dependent error vector. Equation (2) are outer model for reflective variables and will be used for dependent variables. Equation (3) is outer model are formative variables and will be used for independent variables. 


\section{RESULTS AND DISCUSSION}

\section{Characters of Respondents}

Table 1. Respondents Characteristics

\begin{tabular}{cccc}
\hline & Criteria & People & $\begin{array}{c}\text { Percentage } \\
(\boldsymbol{\%})\end{array}$ \\
\hline \multirow{2}{*}{ Gender } & Male & 35 & 68 \\
& Female & 16 & 32 \\
\hline \multirow{4}{*}{ Age } & $17-25$ & 3 & 6 \\
(years) & $26-35$ & 16 & 31.3 \\
& $36-45$ & 15 & 29.4 \\
& $45-65$ & 17 & 33.3 \\
\hline \multirow{5}{*}{ Education } & Elementary & 15 & 29.41 \\
& JHS & 7 & 13.72 \\
& SHS & 24 & 47.05 \\
& Diploma & 1 & 1.96 \\
& Bachelor & 2 & 3.92 \\
& Master & 2 & 3.92 \\
\hline
\end{tabular}

Source: Primary Data (2020)

Respondents obtained from the assessment of 51 respondents who are organic coffee supply chain actors in Pasuruan Regency. Table 1 shows that there is a percentage of respondents characteristics based on gender, age, and education. Based on gender, most of the respondents are male with an average age from 26-65 years. Also, dominantly respondent have a senior high school as their last education.

\section{Descriptive Statistics}

Table 2. Descriptive Statistics Analysis

\begin{tabular}{ccccc}
\hline Items & Mean & Std. Dev & Skew & Kurt \\
\hline X1 & 3.71 & 1.33 & -0.73 & -1.28 \\
X2 & 3.57 & 1.40 & -0.62 & -0.94 \\
X3 & 4.05 & 1.22 & -1.04 & -1.05 \\
Y1 & 4.02 & 1.22 & -0.98 & -0.66 \\
Y2 & 3.89 & 1.14 & -0.6 & -0.77 \\
Y3 & 3.91 & 1.06 & -0.5 & -0.62 \\
\hline
\end{tabular}

Source: Primary Data (2020)

Descriptive Statistic in this research is to interpret the distribution of data with mean, standard deviation, skewness, and kurtosis based on every answer from each question. Each variable has three to four indicator and measured with 1-5 Likert scale. Table 2 shows that the average value of all variables is above 3,5 and above the standard deviation. It means that average respondents agree with the statement submitted in the questionnaire, and the data is less varied.

Skewness as a measure of the distribution of data that is less symmetrical has three values, namely positive values, negative values, and neutral values. The results show that the average data is negative, then the distribution is more on the right and the tail is longer to the left (Brown, 2008). so it can be concluded that the average data is distributed to the right. At the kurtosis value, the value that is owned by each variable is negative and below 3 $(<3)$. A variable kurtosis value of less than $3(<3)$ indicates that the data is distribute widespreadly (Brown, 2008).

\section{SEM-PLS Analysis}

1. Outer Model

a. Reflective Indicators

Table 3. Convergent Validity and AVE

\begin{tabular}{cccc}
\hline Items & $\begin{array}{c}\text { Loading } \\
\text { Factor }\end{array}$ & P-value & AVE \\
\hline $\begin{array}{c}\text { Standart } \\
\text { Value }\end{array}$ & $>0.70$ & $<0.05$ & $>0.05$ \\
\hline X1 & \multicolumn{2}{c}{ Suppliers } & 0.635 \\
X1.1 & 0.809 & $<0.001$ & \\
X1.2 & 0.819 & $<0.001$ & \\
X1.3 & 0.763 & $<0.001$ & \\
\hline X2 & \multicolumn{2}{c}{ Manufactures } & 0.737 \\
X2.1 & 0.856 & $<0.001$ & \\
X2.2 & 0.857 & $<0.001$ & \\
X2.3 & 0.863 & $<0.001$ & \\
X3 & \multicolumn{2}{c}{ Consumers } & 0.627 \\
X3.1 & 0.617 & $<0.001$ & \\
X3.2 & 0.859 & $<0.001$ & \\
X3.3 & 0.872 & $<0.001$ & \\
\hline
\end{tabular}

Source: Primary Data (2020)

Indicators are valid if they have a value more than $0,7(>0,7)$. If the loading factor between 0,4 to 0,7 , it must analyze the effect if it's removed (Hair et al., 2017). All of the loading factors have value $>0,7$ except $X 3.1$, but it can't be removed because it has a negative effect on variable X3 (Hair et al., 2017).

Hair, et al (2017) explained that the AVE value in a reflective construct must exceed 0.5 (> 0.5 ). Based on table 1, three reflective latent variables have AVE value above 0.5 , so it can be concluded that latent constructs more than average can explain the reflective indicators.

\section{b. Discriminant Validity}

Discriminant validity can be seen from crossloading value and the square root of AVE. If the loading value or square root of AVE is greater than other values in the same column, then the latent variable has been fulfilled (Hair, et al., 2017). In this research, all of cross loading value and the square root of AVE is larger than other values in same column.

c. Composite Reliability

Table 4. Composite Reliability

\begin{tabular}{lccc}
\hline & X1 & X2 & X3 \\
\hline $\begin{array}{l}\text { Composite } \\
\text { Reliability }\end{array}$ & 0.839 & 0.894 & 0.831 \\
\hline
\end{tabular}

Source: Primary Data (2020) 
A questionnaire have good composite reliability if the composite reliability value larger than 0.7 (> 0.7) (Solimun, et al., 2017). Based on table 2, the composite reliability value of each variable is more than $0.7(>0.7)$ which means that the latent construct has good and consistent reliability.

d. Formative Indicators

Table 5. Indicator Weights

\begin{tabular}{ccc}
\hline Items & P-value & VIF \\
\hline Standart Value & $<0.05$ & $<3,3$ \\
\hline Y1 & \multicolumn{2}{c}{ Environment Performance } \\
Y1.1 & 0.001 & 1.889 \\
Y1.2 & 0.002 & 1.814 \\
Y1.3 & 0.022 & 1.175 \\
Y1.4 & $<0.001$ & 1.260 \\
\hline Y2 & Social Performance \\
Y2.1 & $<0.001$ & 1.149 \\
Y2.2 & 0.003 & 1.052 \\
Y2.3 & $<0.001$ & 1.149 \\
Y3 & Economy & Performance \\
Y3.1 & $<0.001$ & 1.325 \\
Y3.2 & $<0.001$ & 1.118 \\
Y3.3 & $<0.001$ & 1.313
\end{tabular}

Source: Primary Data (2020)

Table 3 shows that the P-value of each indicator has a value of less than $0.05(<0.05)$ which means that the indicator is significant and reliable (Hair, et al., 2017). In addition, the VIF value of each indicator has a value $<3.3$, indicating that the criteria collinearity is fullfiled does not have a collinearity problem (Hair, et al., 2017). It can be concluded that latent constructs have met the validation requirements for formative constructs.

2. Inner Model

a. Path Coefficients and P-value

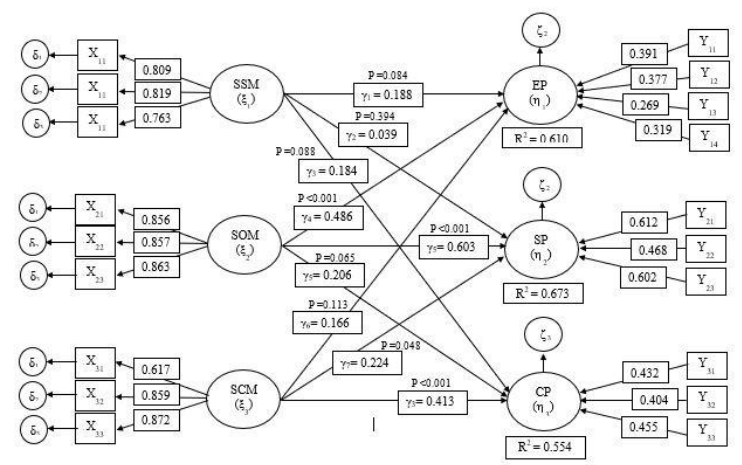

Figure 2. Path Coefficients and P-value
The path coefficient and p-value of the exogenous latent constructs and the endogenous latent constructs can show the hypothetical results. The path coefficient and p-value explain the direct effect of each exogenous latent variable on the endogenous latent variable. Figure 1 shows that the dominant variable has a significant positive effect.

b. $\mathrm{R}$-Square $\left(\mathrm{R}^{2}\right)$ and $\mathrm{Q}$-Square $\left(\mathrm{Q}^{2}\right)$

Table 6. R-Square (R2) and Q-Square (Q2)

\begin{tabular}{lccc}
\hline Items & Y1 & Y2 & Y3 \\
\hline R-Square & 0.610 & 0.673 & 0.554 \\
Q-Square & 0.583 & 0.651 & 0.514 \\
\hline
\end{tabular}

Source: Primary Data (2020)

R-Square as the amount of influence of endogenous variables that can be explained by exogenous variables have three criterias. If $\mathrm{R}^{2}$ more than equal to $0.67(\geq 0.67)$ it's substansial, if $R^{2}$ more than equal to $0.33(\geq 0.33)$ it's moderate category, and if $\mathrm{R}^{2}$ more than equal to $0.19(\geq 0.19)$ it's weak (Suhan and Achar, 2016). Table 5 shows that Y1 and $\mathrm{Y} 3$ into moderate category and $\mathrm{Y} 2$ is large category.

Tabel 6 shows that ree variables have value above 0. Hair, et al (2014) explained that if $\mathrm{Q}^{2}$ is larger than 0 it is considered to have good predictive relevant. It means that in this research variables have good predictive relevant.

c.Full Colinearity VIF

Table 7. Full Colinearity VIF

\begin{tabular}{lllllll}
\hline & X1 & X2 & X3 & Y1 & Y2 & Y3 \\
\hline VIF & 2.83 & 3.46 & 3.20 & 2.83 & 2.72 & 2.16 \\
\hline
\end{tabular}

Source: Primary Data (2020)

VIF is used to determine the collinearity of the latent constructs (Hair, et al., 2017). The ideal value for VIF value is below 3,3 and just above $0,2(>0,2)$ and below $5(<5,5)$. Table 7 shows that all of VIF values are below 3,3 it can be concluded that each latent construct is free from collinearity problems.

d. Effect Size $\left(\mathrm{f}^{2}\right)$

Table 8. Effect Size $\left(\mathrm{f}^{2}\right)$

\begin{tabular}{ccc}
\hline Variable & Effect Size & Result \\
\hline $\mathrm{X} 1 \rightarrow \mathrm{Y} 1$ & 0.126 & Intermediate \\
$\mathrm{X} 1 \rightarrow \mathrm{Y} 2$ & 0.025 & Small \\
$\mathrm{X} 1 \rightarrow \mathrm{Y} 3$ & 0.119 & Small \\
$\mathrm{X} 2 \rightarrow \mathrm{Y} 1$ & 0.367 & Large \\
$\mathrm{X} 2 \rightarrow \mathrm{Y} 2$ & 0.486 & Large \\
$\mathrm{X} 2 \rightarrow \mathrm{Y} 3$ & 0.132 & Small \\
$\mathrm{X} 3 \rightarrow \mathrm{Y} 1$ & 0.117 & Intermediate \\
$\mathrm{X} 3 \rightarrow \mathrm{Y} 2$ & 0.162 & Intermediate \\
$\mathrm{X} 3 \rightarrow \mathrm{Y} 3$ & 0.293 & Intermediate \\
\hline
\end{tabular}

Source: Primary Data (2020) 
Table 9. Structure Parameter Estimates

\begin{tabular}{ccccc}
\hline Variables & Hypothesis & Path Coefficients & P-value & Result \\
\hline $\mathrm{SSM} \rightarrow \mathrm{EP}$ & $\mathrm{H} 1$ & 0,188 & $0,084^{* *}$ & Supported \\
$\mathrm{SSM} \rightarrow \mathrm{SP}$ & $\mathrm{H} 2$ & 0,039 & $0,394^{* *}$ & Not Supported \\
$\mathrm{SSM} \rightarrow \mathrm{CP}$ & $\mathrm{H} 3$ & 0,184 & $0,088^{* *}$ & Supported \\
$\mathrm{SOM} \rightarrow \mathrm{EP}$ & $\mathrm{H} 4$ & 0,486 & $<0,001^{*}$ & Supported \\
$\mathrm{SOM} \rightarrow \mathrm{SP}$ & $\mathrm{H} 5$ & 0,603 & $<0,001^{*}$ & Supported \\
$\mathrm{SOM} \rightarrow \mathrm{CP}$ & $\mathrm{H} 6$ & 0,206 & $0,065^{*}$ & Supported \\
$\mathrm{SCM} \rightarrow \mathrm{EP}$ & $\mathrm{H} 7$ & 0,166 & $0,113^{*}$ & Not Supported \\
$\mathrm{SCM} \rightarrow \mathrm{SP}$ & $\mathrm{H} 8$ & 0,224 & $0,048^{*}$ & Supported \\
$\mathrm{SCM} \rightarrow \mathrm{CP}$ & $\mathrm{H} 9$ & 0,413 & $<0,001^{*}$ & Supported \\
\hline
\end{tabular}

* significant at $1 \%$ level, $* *$ significant at $5 \%$ level, $* * *$ significant at $10 \%$ level.

Source: Primary Data (2020)

Hair, et al (2017) explained that effect size as a change of the endogenous latent construct because the effect of exogenous latent construct divided into three categories, variable has a small effect if the value more than $0,02(>0,02)$, the variable has moderate effect if value more than $0,15(>0,15)$, and variable has large effect if the value more than 0,35 $(>0,35)$.

\section{DISCUSSION}

The results show in table 9 that SSM has a positive and significant effect on EP and CP. Farmer groups select farmers with several conditions or qualifications, such as land area, the three-year trial period for organic land, and others. Sivestri, et al (2020) stated that organizations must be able to do sustainability with their suppliers, such as by increasing supplier competencies. This will lead to an increase in the sustainable demands of the environment. Also, empirical data shows that the government through farmer groups provides training and education, such as training in organic farming, using manure, making vegetable pesticides, training on financial management, and others. Reinhardt in Wang (2013) states that sustainable suppliers who practice environmentally-oriented practices can help reduce costs through environmental efficiency and will affect economic performance.

The results show that SSM has positive yet No. significant effect on SP. It seems that supplier development can't obtain social performance because the suppliers consider that they are not get binded by social regulations between the farmer groups and the community outside the group.

Tabel 9 shows that SOM has an influence on EP. Silvestri, et al. (2020) explained that the complexity in sustainable operations results in investing in technology, increasing competence or quality, and engaging more deeply in the supply chain. This will make demands for sustainability increase, especially in the environmental context. The farmer groups pay attention to the quality of the product, starting with good yields, according to their criteria, and cultivating them organically. The processing of organic coffee follows environmental regulations imposed by the government and $\mathrm{t}$ can improve their environmental performance.

MOB has a positive and significant effect on SP. Improvement for a quality product, variation product, organic processing attract more consumers and get more consumer satisfaction. Giovanni (2012) states that attitudes or activities with environmental strategies will improve social performance.

MOB has a significant positive effect on EP because farmer groups get demand to have quality products that are environmentally friendly and can be produced sustainably; it makes them have neat processing financial data. So far, the operations department has also always conducted trials of new product variations that they can sell, these trials have also been calculated so as not to disrupt the distribution of supplier income. Esfahbodi, et al. (2017) explain that sustainable operations management with high quality and sustainable products can improve economic performance.

The results showed that SCM has a positive yet no significant effect on environmental performance. The results contradict with research by Pekovic, et al (2016), which found that sustainable consumer management has a positive effect on environmental performance. Research conducted by Mirta and Datta (2013) in developing countries concluded that the low level of awareness of environmentally friendly products could lead to less acceptance of products in the market. Empirical data shows that farmer groups feel consumers do not affect environmental performance because their organic products are not the main reason consumers 
interested with their product, consumers turned out to be more interested with prices that fit the market.

Table 9 shows that MKB has positive and significant effect on SP and EP. The farmer groups always try to improve the uniqueness and quality of the products, this needs the development of human resources and also try to build relationships with consumers either directly or on social media and exchange information related to products, receive criticism and suggestions, and feedback so that they can establish a continuity of relationship with consumers and consumers are satisfied. Chen and Lin (2015) said that the exchange of information and experiences with consumers could create customer satisfaction. This consumer satisfaction will make social communication sustainable and increase longterm social performance.

Build good relationships with consumers directly and indirectly as well as exchange information, receive criticism or suggestions from consumers, and consider feedback given by consumers help farmer groups to understand consumers more and know what consumers want so that they try to improve product quality based on consumer needs. Iy can be concluded that this orientation towards consumers makes farmer groups try to maximize the development of their organic coffee products. Alawiyah and Humairoh (2017) state that consumer orientation can help companies understand consumers deeply, improve their services, and make better innovations to maximize the quality that can be provided to consumers so as to maintain relationships with consumers.

\section{CONCLUSION}

This research aim is to analyze the influence of sustainability supply chain management on sustainable performance in organic coffee using sustainability principle and SSCM practices. Organic coffee, as a coffee with the organic farming system, have an important role in Indonesia economy and high prospect due to the large scale of production in Indonesia. This research used SSCM practices with main focus on actors in supply chain and Triple Bottom Line as the basis for sustainable performance.

Variables in this research Based on the results of research, it can be confirmed that variables of sustainable supply chain management practices (sustainable supplier management, sustainable operation management, and sustainable consumer management) have a positive influence on sustainable performance (environmental performance, social performance, and economic performance) and some variables require improvement to be able to significantly influence performance.

On the basis of these findings, there are suggestions for further research and improve sustainability performance.

- Improve product promotion using organic farming systems. Dominantly consumers are not aware of the importance of organic farming systems. Therefore, farmer groups are expected to provide education on their coffee products that have used the organic coffee system.

- Socialize to members of farmer group about environmental and social regulations frequently. Many farmer group members do not know about environmental regulations that have been set by the government, they know only verbally and from stakeholders.

- For further research, add more indicators of each variable from outside the model and always be adjusted to theory and empirical data. This is to know more deeply about other factors that influence sustainability performance.

\section{REFERENCES}

Ahi, P., \& Searcy, C. (2013). A comparative literature analysis of definitions for green and sustainable supply chain management. Journal of Cleaner Production, 52, 329-341.

Alawiyah, I., \& Humairoh, P. N. (2017). The impact of costumer relationship management on company performance in three segments. Jakarta: Gunadarma University.

APICS SCC. (2016). Supply chain sustainability: uncovering the triple bottom line. Kansas, Amerika Utara: APICS INSIGHTS AND INNOVATIONS.

Central Bureau of Statistics. (2018). Coffee plantation production by regency or city in East Java. Online: jatim.bps.go.id. Accessed on Januari 12, 2020.

Bleomhof-Ruwaard, J. (2019). Sustainable supply chains for the future. Online: researchgate.net. Accessed on Januari 5, 2020.

Brown, S. (2008). Measures of shape: skewness and kurtosis. Diakses dari https://brownmath.com/stat/shape.html.

Chen, S. C., \& Chieh-Peng, L. (2015). The impact of customer experience and perceived value on sustainable social relationship in blogs: 
An empirical study. Technological Forecasting \& Social Change, 96, 40-50.

Ministry of Agriculture, Directorate General of Plantation. (2018). Indonesian Plantation Statistics 2017-2019. Jakarta: Secretariat of the Directorate General of Plantation.

Emamisaleh, K., \& Rahmani, K. (2017). Sustainable supply chain in food industries: drivers and strategic sustainability orientation. Cogent Business \& Management, 4(1), 1-18.

Esfahbodi, A., Zhang, Y., Watson,G., and Zhang, T. (2017). Governance pressures and performance outcomes of sustainable supply chain management - an empirical analysis of UK manufacturing industry. Journal of Cleaner Production. 155(2), 66-78.

Giovanni, D. P. (2012). Do internal and external environmental management contribute to triple bottom line?. Internasional Journal of Operations \&Production Management, 32(3), 265-290.

Hair, J. F. JR., Ringle. H. G. T. M., C. M., Sarstedt, M. (2017). A primer on Partial least squares structural equation modeling (pls-sem) second edition.California: SAGE Publication

Heizer, J. \& Render, B. (2015). Operations Management: 11th. Jakarta: Salemba Empat.

Lu, H. E., Potter, A., Rodrigues. V. S., Walker, H. (2018). Exploring sustainable management: a social network perpective. Cardiff, UK: Cardiff University.

Mitra, S \& Datta, P. P. (2013). Adoption of green supply chain management practices and their impact on performance: an exploratory study of Indian manufacturing firms. International Journal of Production Research, 52:7, 20852107.
Narimissa, O., Kangarani. F. A., \& Zavardehi, S. M. A. Z. (2019). Evaluation of sustainable supply chain management performance: Indicators. Sustainable Development, 2019, 1-14.

Silvestri, C, Piccarozzi. M., Aquilani, B. (2020). Customer satisfaction and sustainability initiatives in the fourth industrial revolution. US: IGI Global.

Solimun, A., Fernandes, A. R., \& Nurjannah. (2017). Metode statistika multivariat Pemodelan Persamaan Struktual (SEM) Pendekatan WarpPLS. CV. Citra: Malang.

Suhan \& Achar, A. P. (2016). Assessment of PLSSEM Path Model for Coefficient of Determination and Predictive Relevance of Consumer Trust on Organic Cosmetics. Ushus - Journal of Business Management, 15(4),

$1-19$. https://doi.org/10.12725/ujbm.37.1

Wang, Z. \& Sarkis, J. (2013). Investigating the relationship of sustainale supply chain management with corporate financial performance. International Journal of Productivity and Performance Management, Vol. 62 No. 8, 2013. 
This page is intentionally left blank 